\title{
ORAL MANIFESTATIONS OF CELIAC DISEASE
}

Milos Zivic ${ }^{1}$, Jelena Zivic ${ }^{2}$, Ziva Zivic ${ }^{3}$, Natasa Zdravkovic ${ }^{2,3}$

${ }^{1}$ University of Kragujevac, Serbia, Faculty of Medical Sciences, Department of Dentistry

${ }^{2}$ University of Kragujevac, Serbia, Faculty of Medical Sciences, Department of Internal medicine

${ }^{3}$ Clinical Center Kragujevac, Clinic for Interne medicine, Center for Gastroenterohepatology

\section{ORALNA MANIFESTACIJA CELIJACNE BOLESTI \\ Miloš Živić ${ }^{1}$, Jelena Živić ${ }^{2}$ Živa Živić ${ }^{3}$, Nataša Zdravkovićé, \\ ${ }^{1}$ Univerzitet u Kragujevcu, Srbija, Fakultet medicinskih nauka, Odsek za stomatologiju \\ ${ }^{2}$ Univerzitet u Kragujevcu, Srbija, Fakultet medicinskih nauka, Katedra za internu medicinu \\ ${ }^{3}$ Klinički centar Kragujevac, Klinika interne medicine, Centar za gastroenterologiju}

\begin{abstract}
Celiac disease $(C D)$ is chronic inflammatory disease of the proximal small intestine. It is caused by hypersensitivity to gluten proteins, rays and barley, which damage the intestinal mucous membrane, creating conditions for malabsorption. In addition to intestinal, classic forms of the disease, extraintestinal manifestations may occur. Aphthae in the oral cavity, defects of the enamel, caries, delayed tooth erupting, atrophic glossitis and angular cheilitis are some of them. Serological examination of patients with minimal symptoms and in patients with extraintestinal and atypical gastrointestinal symptoms would improve the timely diagnosis. By careful dental examination of the cavity with a special focus on these changes, we can contribute to early diagnosis of the $C D$. The education of patients about oral manifestations of $C D$ can improve the quality of life of these patients.
\end{abstract}

Keywords: celiac disease, oral manifestations, recurrent aphthous stomatitis, enamel defects.

\section{SAŽETAK}

Celijačna bolest (engl. Celiac disease, $C D$ ) je hronična inflamacijska bolest proksimalnih partija tankog creva. Izazvana je preosetljivošću na proteine glutena, raže i ječma, koji oštećuju sluznicu creva stvarajući uslove za nastanak malapsorpcije. Pored intestinalnih, klasičnih formi bolesti mogu se javiti i ekstraintestinalne manifestacije. Afte u usnoj duplji, defekti gledi, karijes, zakasnelo nicanje zuba, atrofični glositis $i$ angularni heilitis su neke od njih. Serološko ispitivanje pacijenata sa minimalno izraženim simptomima i kod pacijenata sa ekstraintestinalnim i atipičnim gastrointestinalnim tegobama, poboljšalo bi pravovremenu dijagnozu. Pažljivim stomatološkim pregledom usne duplje sa posebnim fokusom na ove promene, možemo doprineti ranoj dijagnozi CD. Edukacija pacijenata o oralnim manifestacijama CD može poboljšati kvalitet života ovih pacijenata.

Ključne reči: celijačna bolest, oralne manifestacije, rekurentni aftozni stomatitis, gleđni defekti

\section{ABBREVIATIONS:}

CD - Celiac disease

HLA DQ2 - Human leukocyte antigen DQ2

HLA DQ8 - Human leukocyte antigen DQ8

IgA - Immunoglobulin A

IgG - Immunoglobulin G
GIT - Gastrointestinal tract

TTG - Tissue transglutaminase

EMA - Endomysial antibody

RAS - Recurrent aphthous stomatitis

AIDS - Acquired immune deficiency Syndrome

\section{sciendo}

DOI: 10.2478/sjecr-2019-0009 


\section{INTRODUCTION}

Celiac disease (CD) is a chronic inflammatory disease of the proximal small intestine. It is caused by hypersensitivity to gluten proteins, rays and barley, which damage the mucous membrane, creating conditions for malabsorption. Celiac disease is a hereditary disease with a predisposition $5-15 \%$ of developing disease in close relatives (first and second generation). Gene alleles HLA DQ2 (Human Leukocytes Antigen DQ2) and HLA DQ8 (Human Leukocytes Antigen DQ8) heterodimers are present in $90 \%$ of patients (1).

The prevalence of CD in Europe and America is approximately the same and it is $0.5-1.0 \%$ of the total population (2). In Europe, prevalence of CD was found to vary from $0.3 \%$ in Germany to $2.4 \%$ in Finland (3).

Due to the presence of these gene alleles, an immune response to gluten proteins occurs when they come in contact with the mucous membrane. In the serum of patients suffering from CD, IgA (Immunoglobulin A) antibodies and IgG (Immunoglobulin $\mathrm{G}$ ) antibodies are produced, which are specific for transglutaminase A2, the enzyme present in all tissues including GIT (Gastrointestinal tract) submucosa. Transglutaminase A2 modifies the gluten protein glyadine. The complexes transglutaminase-glyadine activate B lymphocytes by endocytosis. Activated B lymphocytes produce autoantibodies that present glyadine peptides to helper $\mathrm{T}$ lymphocytes. These cells play a key role in the humoral immune response. Cytotoxic CD8+ T lymphocytes directly damage epithelial cells with perforins, as well as the induction of epithelial cells into apoptosis due to the high expression of Fas ligand on their own surface. The consequence of chronic mucosal inflammation is villous atrophy, malabsorption and nutritional defects (iron, calcium, folate and liposoluble vitamins) (3).

The consequences of nutritional defects are also manifestations of the skin. Dermatitis herpetiformis During is a skin manifestation of CD characterized by chronic itching and rash that does not respond to conventional therapy. Skin biopsy is necessary to confirm the diagnosis, and as in CD, the therapy is a gluten-free diet (1).

The disease can be diagnosed at any time of life, and the most often in the third and fourth decade. Intestinal symptoms are manifested in the form of chronic or intermittent diarrhea, abdominal pain, meteorism with loss of body weight or in the form of constipation, anorexia and vomiting. In addition to intestinal, classic forms of the disease, extraintestinal manifestations may occur. Aphthae in the oral cavity, defects of the enamel, caries, delayed tooth erupting, atrophic glossitis and angular cheilitis are some of them. In the children's population, frequent consequences of CD are inadequate growth and development and late puberty $(4,5)$.

Specific and sensitive serological tests have a role in diagnosis of CD. This is a serum IgA test of tissue transglutaminase (TTG) antibodies and endomysial antibody test (EMA).
Their sensitivity and specificity are greater than $90 \%(1,2)$. Immunoglobulin A deficiency is a common feature in celiac disease, and serum IgA levels have to be determined to avoid a false negative result. Although the sensitivity and specificity of these tests in children under 3 years of age is lower, negative test does not exclude CD. It is necessary to do a biopsy of the small intestine in patients with a positive serological test to confirm the diagnosis. Serological examination of patients with minimal symptoms and in patients with extraintestinal and atypical gastrointestinal problems would improve the timely diagnosis (2).

\section{ORAL MANIFESTATIONS}

\section{Recurrent aphthous stomatitis}

The most common inflammatory condition in the oral cavity is recurrent aphthous stomatitis (RAS) (6). It occurs in $10-20 \%$ of the general population. It is manifested in the form of recurrent small, round or elliptic ulcerations, surrounded by erythematous halo, covered with yellow-gray pseudomembranes. It is more often manifested in a child's population with inadequate nutrition, immune deficiency, malabsorption, and CD $(6,7)$.

The etiology of RAS is still unknown. Significant etiological factors include: local and microbial factors, systemic diseases, psychological stress, food allergies, immune deficiency, hormonal imbalances and inadequate nutrition. Local factors such as local trauma, bad dental fillings and carious teeth may cause RAS. Some of the systemic diseases in which RAS can occur as a manifestation are Behcet's syndrome, cyclic neutropenia, AIDS (Acquired Immune Deficiency Syndrome), Chron's disease. Drugs such as $\beta$-blockers and non-steroidal anti-inflammatory drugs can cause RAS $(8,9)$.

Aphthae appears on the non-keratinizing mucous membrane of the oral cavity (Figure 1).

Figure 1. Aphthae on mucous membrane of lower lip

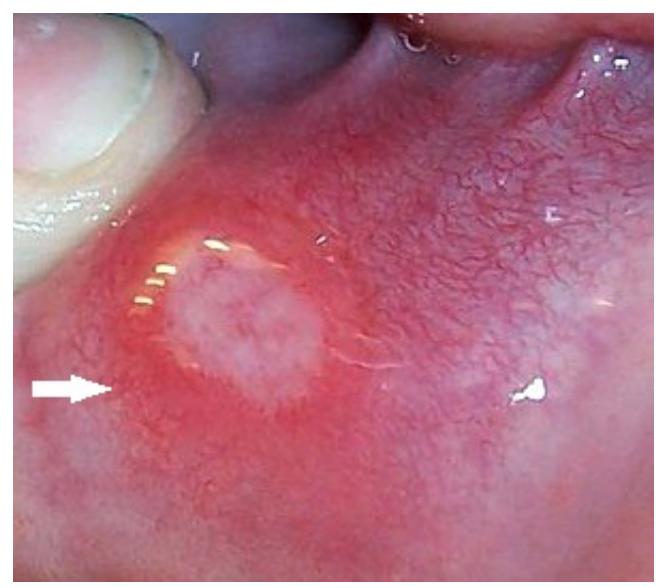


They are characterised by pain that can adversely affect nutrition, speech, swallowing and regular maintenance of oral hygiene. The pain intensity varies from mild to severe. There is a possible occurrence and emotional instability in patients (6). Recurrent aphthous stomatitis as the only manifestation of CD is present in $22.7 \%$ of children suffering from celiac disease (7). Previous clinical studies have shown a significant prevalence of RAS of $26 \%$ and $33.3 \%$ in patients suffering from CD (10). In the study of Bramanti and associates, a high prevalence of RAS was observed in patients with CD (52\%) and in the group of patients with suspected CD (66.7\%) (11).

Recurrent aphthous stomatitis is clinically manifested in three forms:

1. The most common form of the disease is in the form of small aphthae. It occurs in about $80 \%$ of patients, with a lesions size less than $5 \mathrm{~mm}$. The most common localization of changes is on the mucous membranes of the lips, buccal mucosa and the floor of the oral cavity, while they are less localized on the gingiva, palate mucosa and dorsal side of the tongue. The lesions are epitelized after 10-14 days without scarring (8).

2. Less common and more severe form of the disease is in the form of large aphthae. In the literature, this form of the disease is described as periadenitis mucosa necrotica recurrens. Lesions can be larger than $1 \mathrm{~cm}$. The most common localization is on the lips, soft palate and throat. In this form of disease, lesions can persist for up to 6 weeks. In a certain number of patients lesions heal leaving a scar (8).

3. The least common form of the disease are herpetiform aphthae. It is characteristic appearance of a large number of small lesions, the size of 2-3mm (Figure 2). Lesions are merging over time, creating large defects on the mucous membrane, which more often heal leaving a scar (8).

Figure 2. Herpetiform aphthae form of recurrent aphthous stomatitis

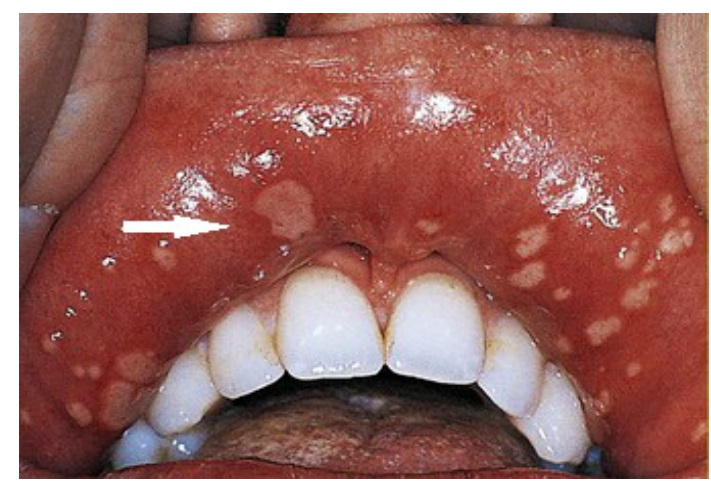

RAS therapy involves the identification and control of possible favorable factors, which can be very challenging, especially in patients with severe disease. When RAS is a secondary manifestation of a disease, it is necessary to diagnose and treat the primary disease. Medical therapy is prescribed only in the case of persistent and very painful forms of RAS.
In patients with constant and aggressive forms, such as large lesions, local and symptomatic therapy is not successful enough. In such situations, systemic corticosteroid therapy is indicated (12).

\section{Enamel defects}

If a disease occurs in children during the development of permanent teeth, i.e. before the age of seven, abnormalities in the structure of dental enamel may occur. Defects are most often present in the permanent dentition, symmetrically in all four quadrants. More often in the region of molars in the upper and lower jaw. Hypoplasia and hypomineralization of the enamel can also occur. A characteristic manifestation is the hypoplasia of enamel in the middle third of the tooth crown, with preserved enamel on the lumps.

Enamel defects in adults are not so common, probably due to later development of the disease. The mechanism of the formation of these defects is not fully understood but is considered to be immune mediated (1). The prevalence of generalized enamel defects in patients with celiac disease in mixed or permanent dentition ranges from 9.5-95.9\% (mean is $51.1 \%$ ), in deciduous dentition it is $5.8-13.3 \%$ (mean $9.6 \%$ ) (1). Such results can be explained by the chronology of the development and maturation of tooth structures. Crowns of permanent teeth develop between the first half of the first and the seventh year of life, when gluten diet is usually introduced, while deciduous teeth develop intrauterine. The presence of enamel defects in deciduous dentition supports the hypothesis that immune and genetic factors are more important in the etiology of defects than nutritive factors (Figure 3) $(13,14)$.

Figure 3. Enamel defects in deciduous teeth

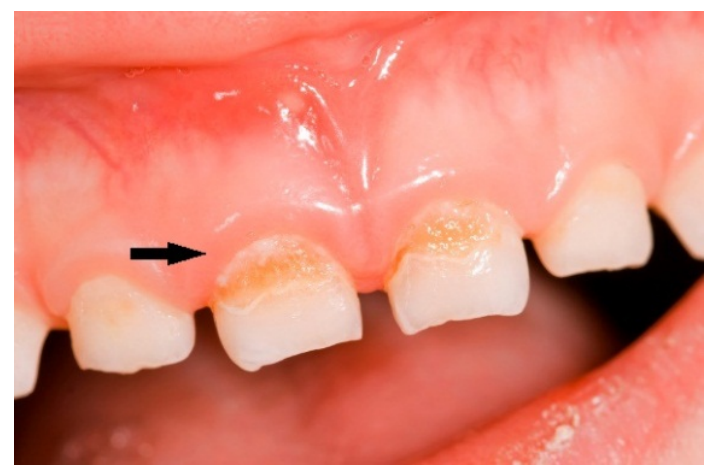

Enamel lesions can occur for many reasons, so their cause should be properly diagnosed. The task of the dentist is to determine whether the etiological factor is systemic, which affects all teeth that develop simultaneously, or local, affecting only one, two or a group of teeth. Hypoplasia of the enamel is easily identified, due to poorly formed enamel or its complete lack. It can manifest in the form of grooves or lines over the tooth surfaces that are normally mineralized (the structure is normally developed). Smooth, but discolored surface of the enamel, yellow or darker color, supports the 
hypocalcification. Fluorosis is another relatively frequent lesion in the enamel $(1,14)$.

\section{Caries}

Some studies have suggested that prevalence of caries in patients with celiac disease is lower compared to healthy subjects. A possible explanation of these results is the controlled diet of patients suffering from celiac disease. These patients maintain gluten-free foods, which can be found in several cariogenic foods, such as oatmeal, flour and bread (13).

However, there is evidence in the literature that in the population of patients with celiac disease the prevalence of caries may be higher than in healthy persons. It is described enamel hypoplasia, changes in composition and secretion of saliva. These factors may be favored for the development of dental caries (13). Reduced salivation is one of the possible manifestations of celiac disease and can be partly caused by gluten-free diet. In such conditions, dry mouth symptoms are possible such as pricking and burning mucous membrane of the mouth. If the humidity of the mucous membrane of the mouth is lowered, the risk of an oral infection, including the caries, is increased (Figure 4). It has been shown that in patients suffering from celiac disease which are on gluten-free diet, the level of amylase can be reduced. Together with lower IgA and IgM levels and lower buffer capacity of the saliva, the survival of microorganisms causing the formation of dental caries is longer $(14,15)$.

Figure 4. Dental caries in cross-sectional view

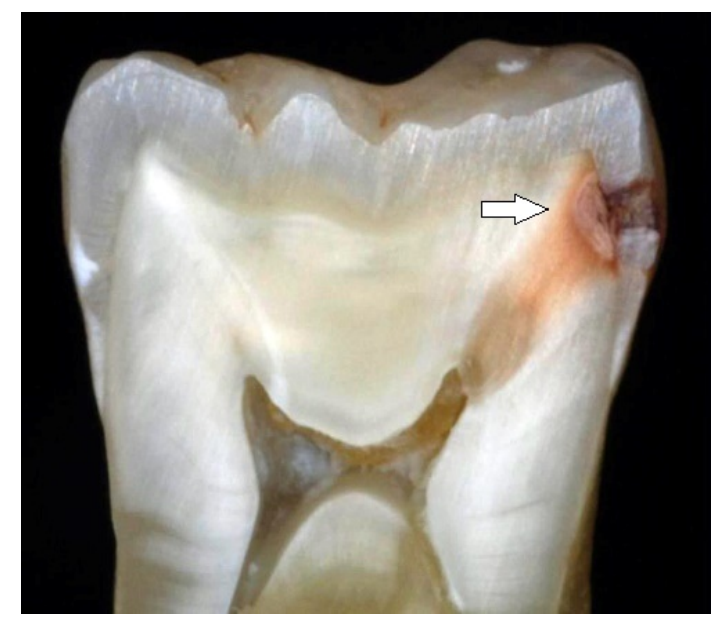

\section{Angular cheilitis}

Angular cheilitis is a manifestation that can occur in patients with CD. It can affect the skin and mucous membranes of the lips. It is characterized by erosion, ulceration, fissures and sores in the corner of the lips (Figure 5). Pain is also possible. In the Bramanti and associates study, angular cheilitis has been demonstrated in $6 \%$ of patients with celiac disease and $9.5 \%$ patients of suspected celiac disease (11).
Figure 5. Dental caries in cross-sectional view

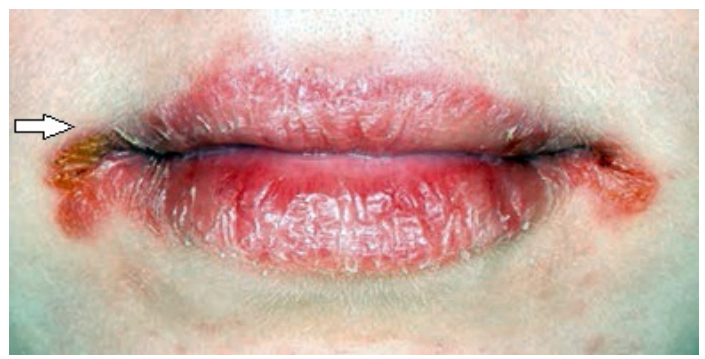

\section{CONCLUSION}

Oral manifestations of celiac disease such as: recurrent aphthous stomatitis, enamel defects, delayed tooth eruption and tongue lesions can be the only ones. During anamnestic questioning and dental examination, a dentist detects one of the possible oral manifestations of celiac disease, it is necessary to inform the patient or family member.

Celiac disease can be effectively treated with gluten-free diet. However, the diet should not be started before taking a biopsy due to regeneration of the mucous membrane, so the interpretation of the biopsy is difficult and can be a false negative diagnosis. Although rarely, it is possible that symptoms occur in patients on a gluten-free diet, which generally occur in population older than 50 years, which represent refractory forms of the CD.

By careful dental examination of the oral cavity with a special focus on these changes, we can contribute to early diagnosis of the CD. The education of patients on oral manifestations of CD can improve the quality of life of these patients.

\section{REFERENCES}

1. Rashid M, Zarkadas M, Anca A LH. Oral manifestations of celiac disease. A case report and review of the literature. Can Dent Assoc 2010; 77: 1-6.

2. Gujral N, Freeman HJ, Thomson ABR. Celiac disease: Prevalence, diagnosis, pathogenesis and treatment. World J Gastroenterol 2012; 18: 6036-59.

3. Wyllie R, Hyams JS, Kay M. Pediatric Gastrointestinal and Liver Disease. Elsevier 2016.

4. Avşar A, Kalayci AG. The presence and distribution of dental enamel defects and caries in children with celiac disease. Turk J Pediatr 2008; 50: 45-50.

5. Cantekin K, Arslan D, Delikan E. Presence and distribution of dental enamel defects, recurrent aphthous lesions and dental caries in children with celiac disease. Pakistan J Med Sci 2015; 31: 606-9. 
6. Krisdapong S, Sheiham A, Tsakos G. Impacts of recurrent aphthous stomatitis on quality of life of 12- and 15year-old Thai children. Qual Life Res 2012; 21: 71-6.

7. Campisi G, Di Liberto C, Carroccio A, Compilato D, Iacono G, Procaccini M, et al. Coeliac disease: Oral ulcer prevalence, assessment of risk and association with gluten-free diet in children. Dig Liver Dis 2008; 40: 104-7.

8. Chavan M, Jain H, Diwan N, Khedkar S, Shete A, Durkar S. Recurrent aphthous stomatitis: a review. J Oral Pathol Med 2012; 41: 577-83.

9. Baccaglini L, Lalla R, Bruce A, Sartori-Valinotti J, Latortue M, Carrozzo M, et al. Urban legends: Recurrent aphthous stomatitis. Oral Dis 2011; 17: 755-70.

10. Procaccini M, Campisi G, Bufo P, Compilato D, Massaccesi C, Catassi C, et al. Lack of association between celiac disease and dental enamel hypoplasia in a casecontrol study from an Italian central region. Head Face Med 2007; 3: 25.

11. Bramanti E, Cicciù $M$, Matacena $G$, Costa $S$, Magazzù G. Clinical Evaluation of Specific Oral Manifestations in Pediatric Patients with Ascertained versus Potential Coeliac Disease: A Cross-Sectional Study. Gastroenterol Res Pract 2014; 2014: 1-9.

12. Edgar NR, Saleh D, Miller RA. Recurrent Aphthous Stomatitis: A Review. J Clin Aesthet Dermatol 2017; 10: 26-36.

13. Macho VMP, Coelho AS, Veloso e Silva DM, Andrade DJC de. Oral Manifestations in Pediatric Patients with Coeliac Disease - A Review Article. Open Dent J 2017; 11 (1): 539-45.

14. De Carvalho FK, De Queiroz AM, Bezerra Da Silva RA, Sawamura R, Bachmann L, Bezerra Da Silva LA, et al. Oral aspects in celiac disease children: Clinical and dental enamel chemical evaluation. Oral Surg Oral Med Oral Pathol Oral Radiol 2015; 119 (6): 636-43.

15. 15. Acar S, Yetkiner AA, Ersin N, Oncag O, Aydogdu $\mathrm{S}$, Arikan C. Oral findings and salivary parameters in children with celiac disease: A preliminary study. Med Princ Pract 2012; 21 (2): 129-33. 